\title{
Using evidence to improve primary health care in Thai Nguyen
} Province

Population Council

Follow this and additional works at: https://knowledgecommons.popcouncil.org/departments_sbsr-rh

Part of the Community Health Commons, Health Policy Commons, International Public Health Commons, Public Health Education and Promotion Commons, and the Women's Health Commons How does access to this work benefit you? Let us know!

\section{Recommended Citation}

"Using evidence to improve primary health care in Thai Nguyen Province." Hanoi: Population Council, 2011. 
USING EVIDENCE TO IMPROVE PRIMARY HEALTH CARE IN THAI NGUYEN PROVINCE

SỬ DUNG BẰNG CHỨNG CẢl THIÊEN CÔNG TÁC CHĂM SÓC SỨC KHỎE BAN ĐÂUU TẠI TİNH THÁI NGUYÊN

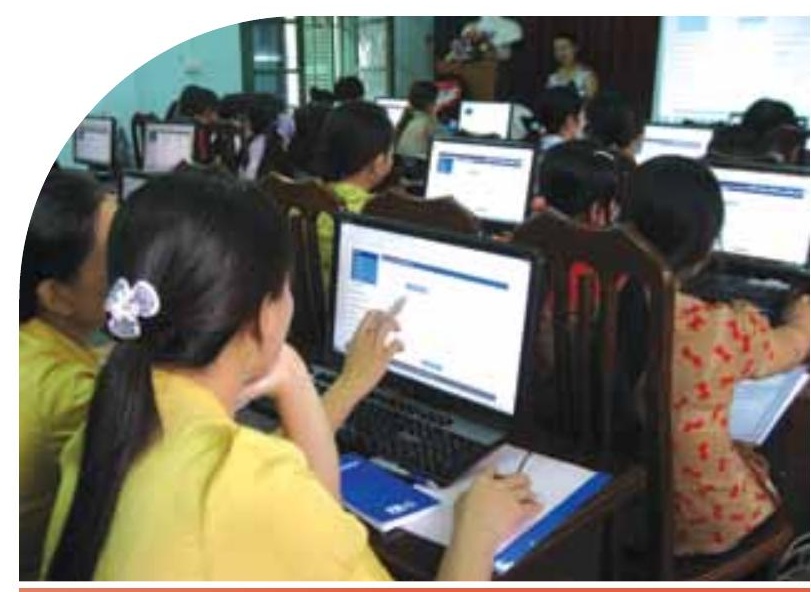

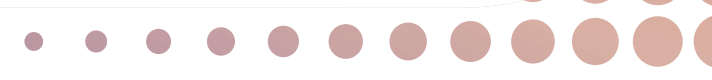

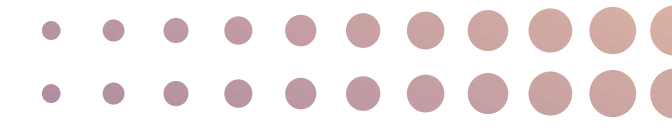

$$
\begin{aligned}
& \text { - } . \bullet \circ 000000 \\
& \text { - } \bullet \bullet \bullet \circ 00000 \\
& \text { - } \bullet \bullet \bullet \circ 00000 \\
& \text { - } \bullet \bullet \bullet \circ 00000
\end{aligned}
$$

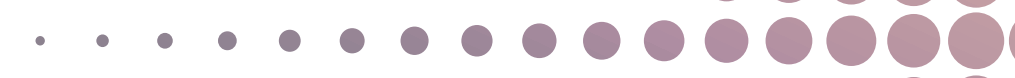

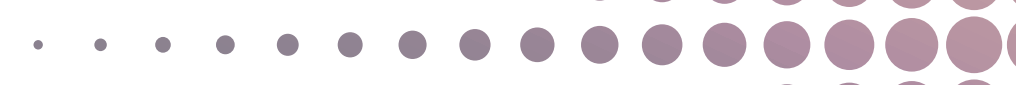

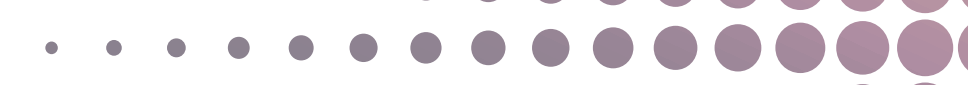

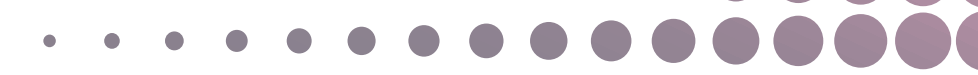

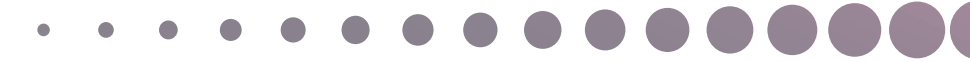

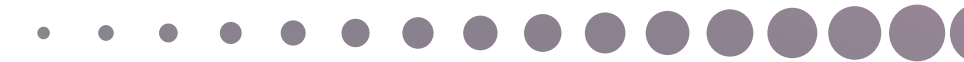

$$
\begin{aligned}
& \text { - } . \cdot-0000000000
\end{aligned}
$$

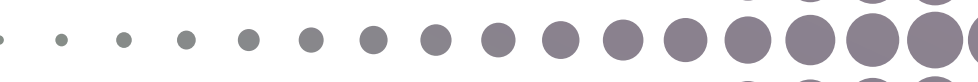

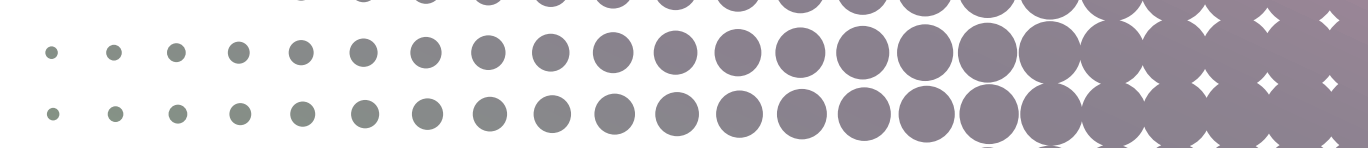

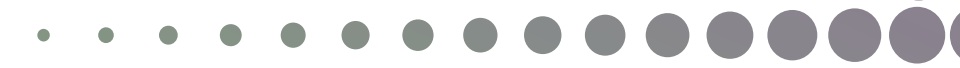

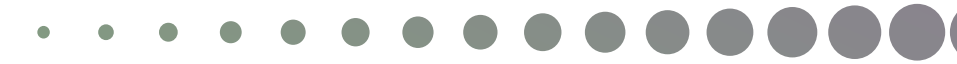

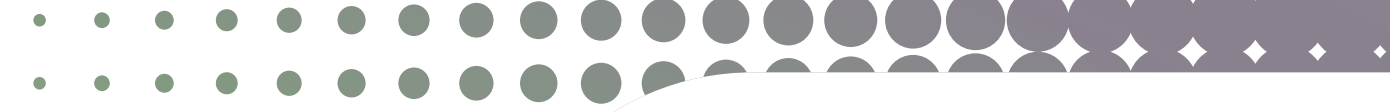

$$
\begin{aligned}
& \bullet \bullet \bullet \bullet \bullet \bullet \bullet \bullet \\
& \text { A Population Council }
\end{aligned}
$$




\section{TÓM TẮT}

Họp tác với Sở Y Tế Thái Nguyên (SYTTN), Cty CP Cung Cấp Giåi Pháp và D!̣ch Vụ Công Nghệ Cao Việt Nam (HSP), Trường ĐH Y Dược Thái Nguyên (ĐHYDTN); Viện Dân Số, Y Tế và Phát Triển và Trường Đại Học Y Hà Nội (ĐHYHN), Hội Đồng Dân Số tại Việt Nam (HĐDSVN) hiện đang làm việc để nâng cao cơ sở bằng chứng sẵn có cung cấp cho các nhà chức trách y tế và để học cách sử dụng các bằng chứng đó để cái thiện y tế tại tỉnh Thái Nguyên. Được xây dựng dựa trên sự hợp tác giữa HODSVN và SYTTN từ năm 2006, dự án hiện tại bao gồm ba (03) mảng chính:

1. Phát triển một hệ thống Quản lý Thông Tin $Y$ Tế xã, phường, th! trấn được máy tính hóa có thể trích xuất ra các báo cáo thường quy nộp lên tuyến huyện, tỉnh và trung ương và có thể đưa ra các màn hình và báo cáo phản hồi nhằm trợ giúp các cán bộ y tế và các nhà quán lý. Hệ thống Quán lý Thông Tin $Y$ tế này sẽ được đưa vào hoạt động hoàn toàn vào năm 2012.

2. Trợ giúp nghiên cứu và năng lực nghiên cứu ở tuyến tỉnh để hiểu tốt hơn về các vấn dề y tế và các dịch vụ y tế tại tỉnh Thái Nguyên. Các báo cáo và tài liệu về các nghiên cứu này sẽ được hoàn thành vào tháng 2 năm 2012.

3. Nâng cao năng lực của các cán bộ quản lý và các cán bộ y tế tại SYTTN dể họ sử dụng tốt hơn các bằng chứng nhằm cái thiện công tác chăm sóc sức khỏe. Đây là một quá trình không có thời điểm kết thúc.

Phần kỹ thuật và các quy trình này sẽ có thể được mở rộng thực hiện trên toàn lãnh thổ Việt Nam.

Dự án này được tổ chức Atlantic Philanthropies tài trợ.

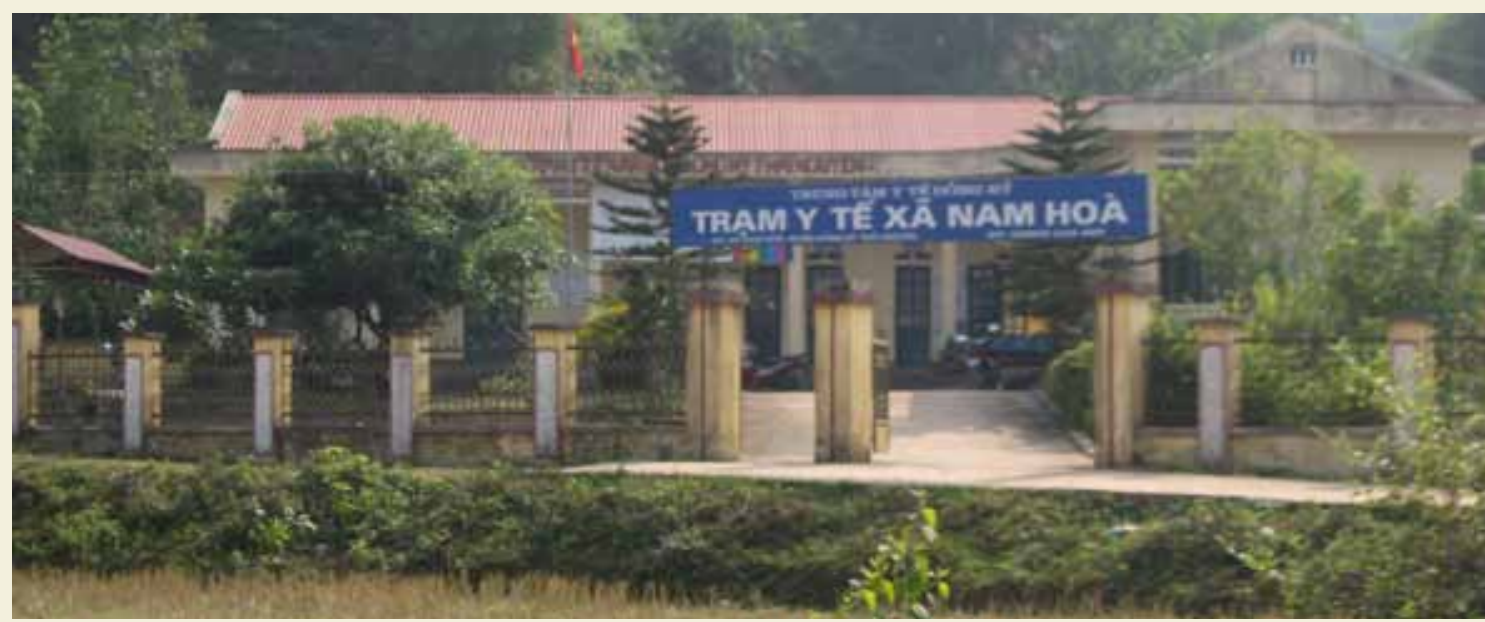




\section{THAI NGUYEN PROVINCE: OVERVIEW}

Thai Nguyen Province, located about 80 kilometers northeast of Ha Noi, is a gateway to Viet Nam's mountainous northeastern region. The population of Thai Nguyen is approximately 1.1 million, 73 percent of whom are Kinh (the ethnic majority in Viet Nam) and 27 percent are Tay, Nung, San Diu, H'mong, San Chay, Dao and Hoa (Chinese) minority groups. The terrain ranges from fertile plains to rugged mountains, with density varying accordingly. Administratively the province consists of seven districts, one city, and one town; these are further divided into 181 communes.

Although one in every four households is poor, the local economy is growing rapidly, with annual GDP growth rates ranging between 7 and 9 percent in recent years. Thai Nguyen Province is a regional center of higher education for the northern region of the country, with five universities and 16 colleges and technical schools. The public health system supports 12 referral hospitals at various levels and purposes, 9 secondary district hospitals, and 181 Commune Health Centers (CHCs), of which 133 have attained national benchmark standards.

There are also more than 300 registered private providers in Thai Nguyen, 65 percent of which are located in Thai Nguyen City, and a large number of unregistered providers throughout the province.

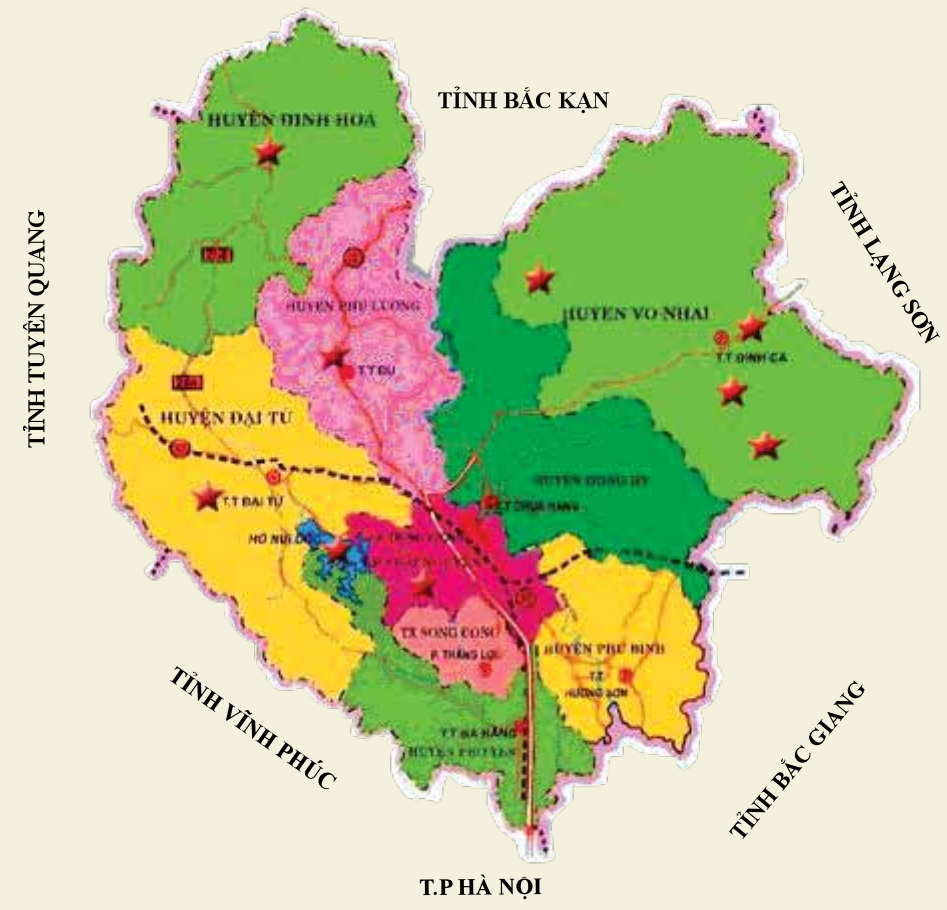




\section{GIÓ́l THIỆU SƠ LƯỢC VỀ TINNH THÁI NGUYÊN:}

Thái Nguyên nằm cách Hà Nội khoảng $80 \mathrm{~km}$ và là cửa ngõ đến với vùng núi Đông Bắc của Việt Nam. Thái Nguyên có dân số xấp xỉ 1,1 triệu người, với $73 \%$ là người Kinh (dân tộc chính của Việt $\mathrm{Nam}$ ) và $27 \%$ là dân tộc thiểu số bao gồm Tày, Nùng, Sán Diu, H'mông, Sán Chày, Dao và Hoa (nguời Trung Quốc). Đ̣̣a hình của Thái Nguyên bao gồm từ đồng bằng màu mỡ đến vùng núi quanh co với mật độ dân số khác nhau. Về mặt hành chính, toàn tỉnh có 7 huyện, 1 thành phố và 1 th! xã và được chia thành 181 xã.

Mặc dù một phần tư hộ dân thuộc diện hộ nghèo, kinh tế của địa phương vẫn tăng trướng nhanh với mức tăng GDP hàng năm từ $7-9 \%$ trong nhưng năm gần đây. Thái Nguyên là trung tâm giáo dục bậc cao của vùng Đông Bắc với 5 truờng Đại học và 16 trường Cao đẳng kỹ thuật. Hệ thống y tế nhà nước bao gồm 12 bệnh viện ở các tuyến và chuyên khoa khác nhau, 9 bệnh viện huyện và 181 Trạm Y Tế Xã (TYT) với 133 TYT đã đạt chuẩn quốc gia.

Ngoài ra tỉnh Thái Nguyên còn có trên 300 cơ sở y tế tư nhân đã đăng ký, với $65 \%$ tập trung ở thành phố Thái Nguyên và một số luợng lớn cơ sở y tế tư nhân vẫn chưa được đăng ký trên toàn tỉnh.
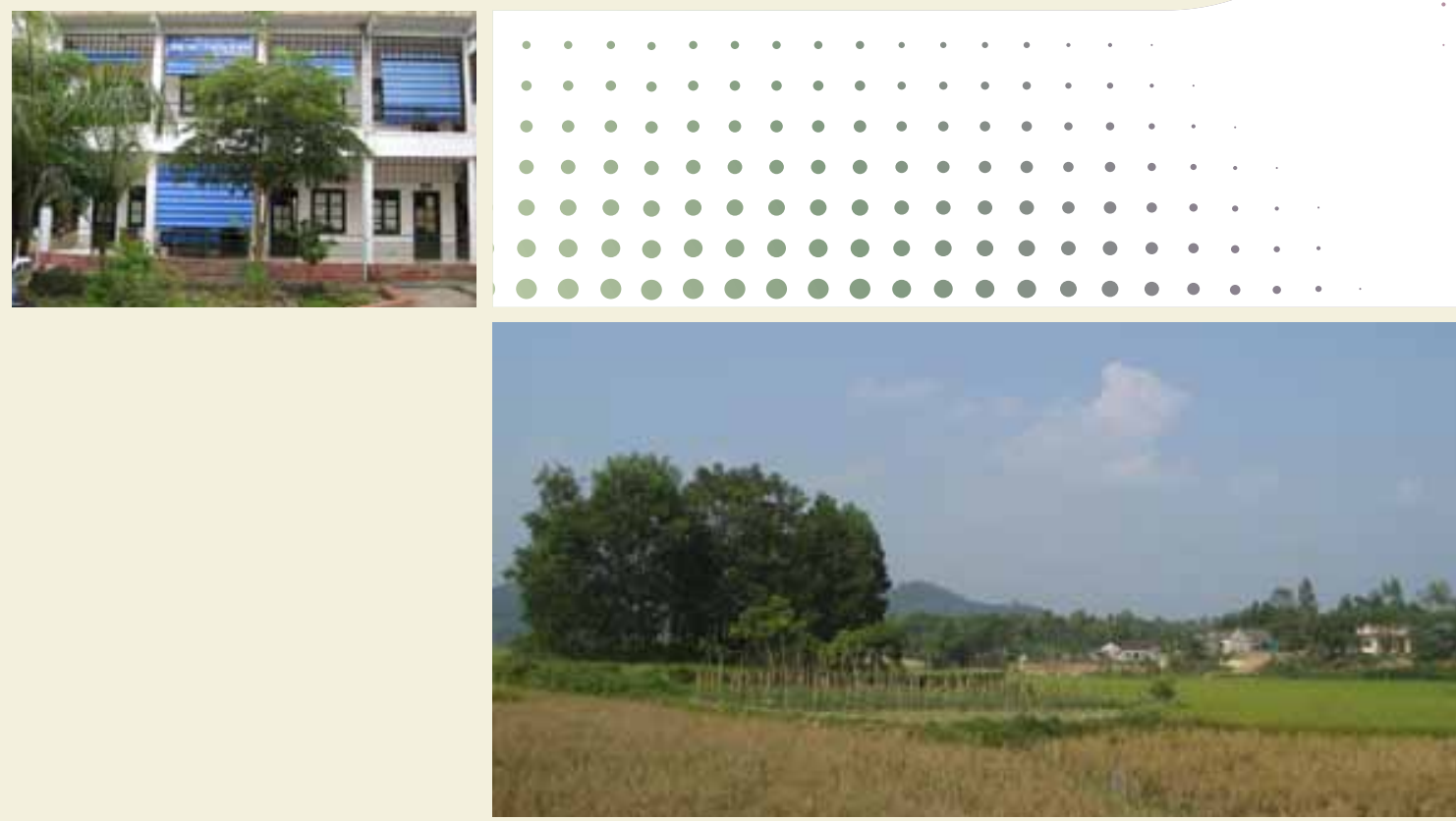


\section{HEALTH ISSUES}

AND IMBALANCES

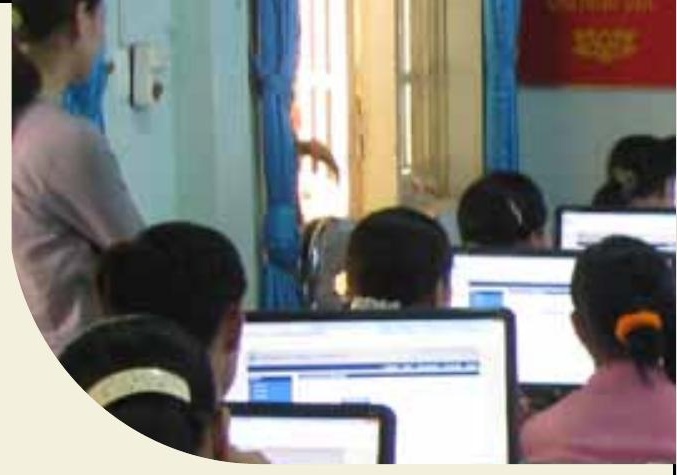

IN THAI NGUYEN

A key challenge for the health sector in Thai Nguyen is addressing the deficiency in health outcomes and healthcare equity among vulnerable groups. The poor and ethnic minority groups utilize $\mathrm{CHCs}$ for primary health care at higher rates, and $\mathrm{CHCs}$ that are far from referral and central hospitals have higher visitation rates; thus there is an opportunity to improve outcomes. However, despite clear differences in service provision needs at different $\mathrm{CHCs}$, resources continue to be distributed disproportionately to more accessible facilities; this issue has not received adequate attention from health authorities. The pattern of diseases has been changing in Viet Nam as well, particularly with the increased prevalence of non-communicable diseases such as hypertension and diabetes.

Understanding these and other healthcare issues in Thai Nguyen is essential for the Health Department to plan effectively. But understanding of these problems is limited because of a lack of accurate information. The current manual record keeping system is inaccurate and slow, limiting the Health Department in using this data efficiently and effectively for evidence-based planning and decision-making. Data are rarely available on service delivery issues such as quality of care, and population-based information, which can allow for in-depth investigation of problems, is often lacking. Inclusion of private providers in databases and their integration within a unified health sector is a major challenge. 

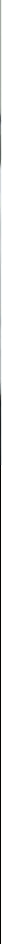

Thách thức chủ yếu đối với ngành y tế của tỉnh Thái Nguyên là dáp úng sự thiếu hụt trong kết quả y tế và sự công bằng trong công tác chăm sóc sức khỏe ở các nhóm dễ bị tổn thương. Nhóm người nghèo và dân tộc thiểu số sử dụng TYT cho nhu cầu chăm sóc sức khỏe ban đầu cao hơn và các TYT càng xa bệnh viện có tỷ lệ đến thăm khám nhiều hơn, do vậy có cơ hội để cái thiện kết quá. Tuy nhiên, mặc dù có sự khác biệt rõ ràng trong việc cung cấp các dịch vụ cần thiết ở các TYT khác, các nguồn lực tiếp tục được phân bổ không cân bằng đối với các cơ sở y tế dễ tiếp cận hơn; vấn đề này vẫn chưa nhận được sự chú ý đúng mức từ các nhà chức trách y tế. Mô hình bệnh tột cũng đã thay dổi ở Việt Nam, đặc biệt là các bệnh không truyền nhiễm phổ biến đang tăng lên như cao huyết áp và đái tháo đường.

Hiểu biết về các vấn dề này và các vấn dề khác trong công tác chăm sóc sức khỏe tại Thái Nguyên là rất cần thiết cho SYTTN dể lập kế hoạch một cách hiệu quả. Nhung nhứng hiểu biết về các vấn đề này hiện nay còn hạn chế vì thiếu thông tin chính xác. Hẹ thống sổ sách báo cáo ghi chép bằng tay hiện tại thiếu chính xác và chậm. Điều này làm SYTTN giám khả năng sử dụng các số liệu một cách hiệu quả trong việc sư dụng bằng chúng để lập kế hoạch và ra quyết định. Nhưng số liệu giúp cho việc tim hiểu sâu hơn về các vấn đề liên quan đến dịch vụ y tế nhu chất lượng dịch vụ và các thông tin liên quan đến dân số hiếm khi có sắn. Việc đưa khối y tế tư nhân tham gia vào cơ sở dữ liệu và thống nhất quản lý thông tin trong ngành y tế là một thách thức lớn. 


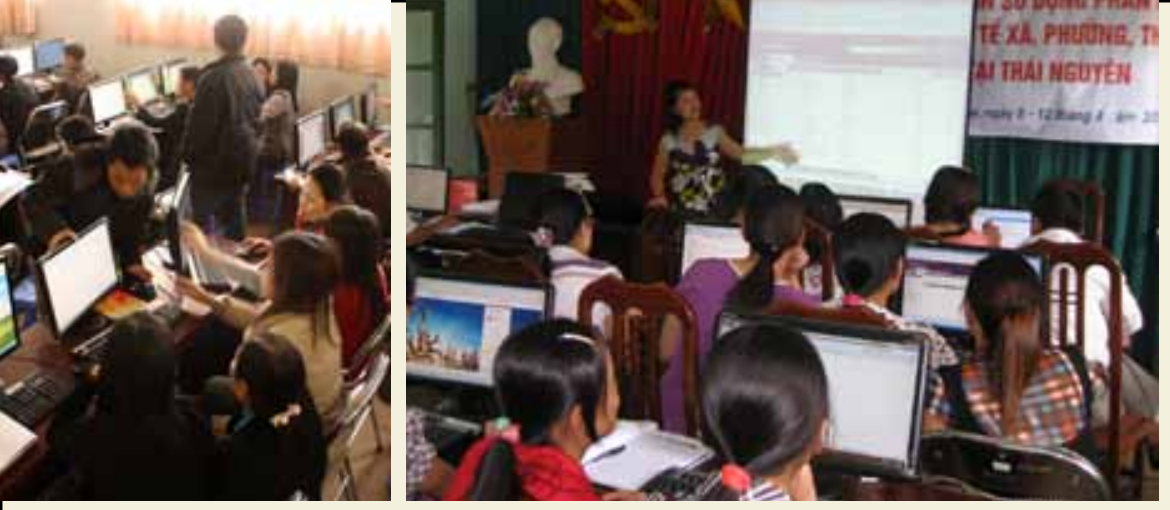




\section{TỰ ĐộNG HÓA VÀ SỬ DỤNG HỆ THỐNG QUẢN LÝ THÔNG TIN Y TẾ}

Thông qua công ty HSP, công ty đối tác phát triển phần mềm, HĐDSVN và SYTTN đang trong quá trinh tin học hóa các mẫu biểu và báo cáo tại tuyến xã. Toàn bộ các TYT hiện nay đã được trang b! máy tính và mỗi TYT có 2 cán bộ đã được đào tạo về cách sử dụng. Cán bộ y tế nhập liệu trực tiếp vào dứ liệu dân số và khám chữa bệnh, chăm sóc bà mẹ và trẻ em, sử dụng dược phẩm và một số các dịch vụ khác tại tuyến xã. Các số liệu sẽ tự động cập nhật vào các mẫu biểu báo cáo quý và thường quy hiện đang lư hành và sẽ chuyển lên tuyến huyện, nơ các báo cáo sẽ tiếp tục tự động được chuyển lên tuyến tỉnh và tuyến trung ương. Đến năm 2012 toàn bộ các báo cáo thuờng quy trích xuất từ dữ liệu của tuyến xã sẽ được thực hiện bằng máy tính.

Các màn hình dữ liệu cho cán bộ tuyến xã đang được xây dưng để giúp cán bộ y tế tuyến xã có thể thực hiện công việc của minh, ví dụ nhu danh sách trẻ em chưa được tiêm chủng hoọ̆c trẻ em suy dinh dưỡng cần phải được tư vấn và điều tr!̣. 1/3 thời gian của cán bộ y tế tuyến xã dùng để ghi chép sổ sách báo cáo, khi thời gian này giám mạnh, cán bộ y tế tuyến xã có thể dành nhiều thời gian hơn và hiệu quả hơn trong việc chăm sóc bệnh nhân.

Cùng lúc đó, các báo cáo phản hồi thường quy từ tuyến huyện xuống tuyến xã và từ tuyển tỉnh xuống tuyến huyện đang được xây dụng, thúc dẩy việc quản lý bằng sử dụng số liệu mà không cần chuyên gia phân tích.
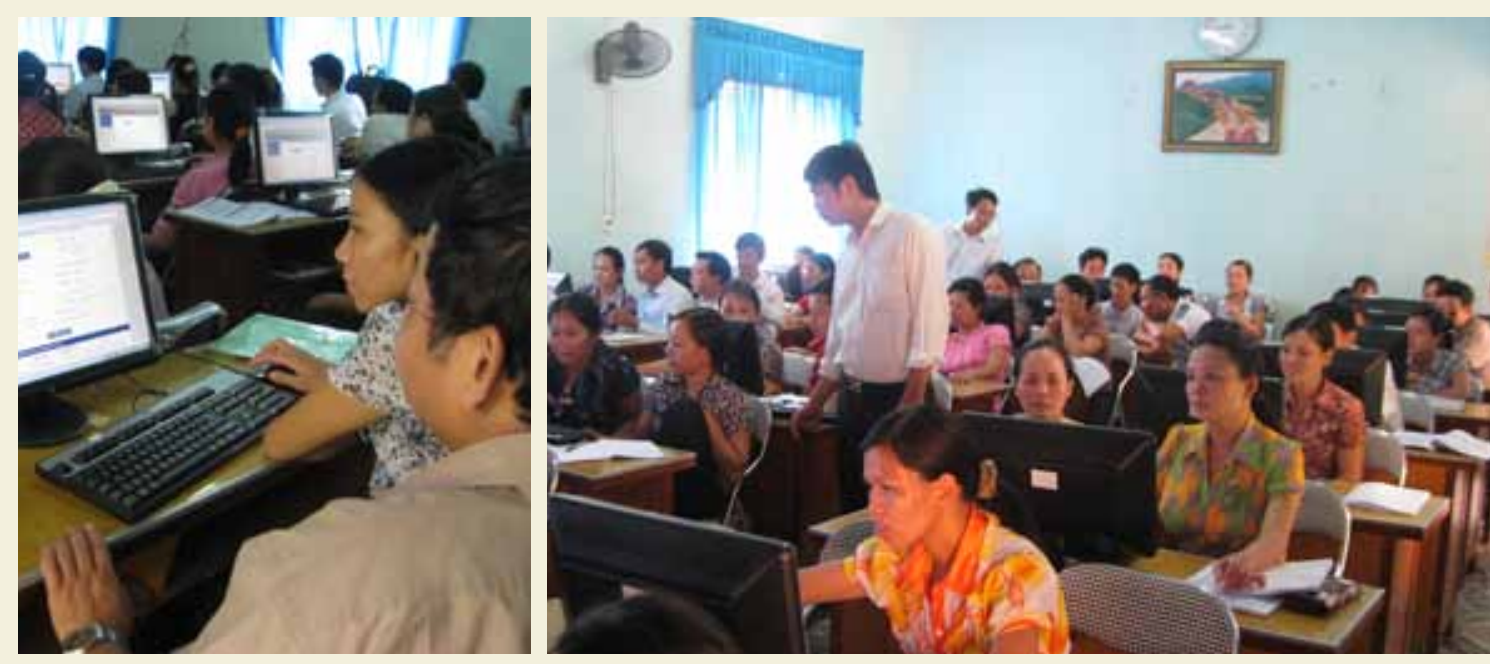


\section{IMPLEMENTING RESEARCH TO UNDERSTAND HEALTH PROBLEMS IN THAI NGUYEN}

Routine statistics from $\mathrm{CHC}$ s cannot provide all the information needed to evaluate and improve the functioning of a health system. Special efforts are needed to identify the health problems affecting a commune's people, and to determine how they deal with those problems. Investigation is needed to evaluate the quality of care provided by the $\mathrm{CHC}$ and to assess the accuracy of its data. It is important to understand when and why people utilize the private health care system, and what quality of care they obtain when they go. It is not necessary for a provincial health department to carry out such studies, but they should know what information they need, how to obtain it, and how to interpret it.

PCVN is working through two partners to model this process by investigating issues of particular interest in TN. TNUMP is conducting a study focused on understanding the use of abortion and the nature and quality of abortion care. PHAD is looking at the nature and quality of the private health care system in $\mathrm{TN}$, at people's knowledge and behavior regarding hypertensive diseases, and at reproductive health behavior, as well as evaluating the impact of the computerized HMIS on CHC functioning. TNHD is following these studies, and will work with PCVN and its partners to improve its ability to interpret and use their results.

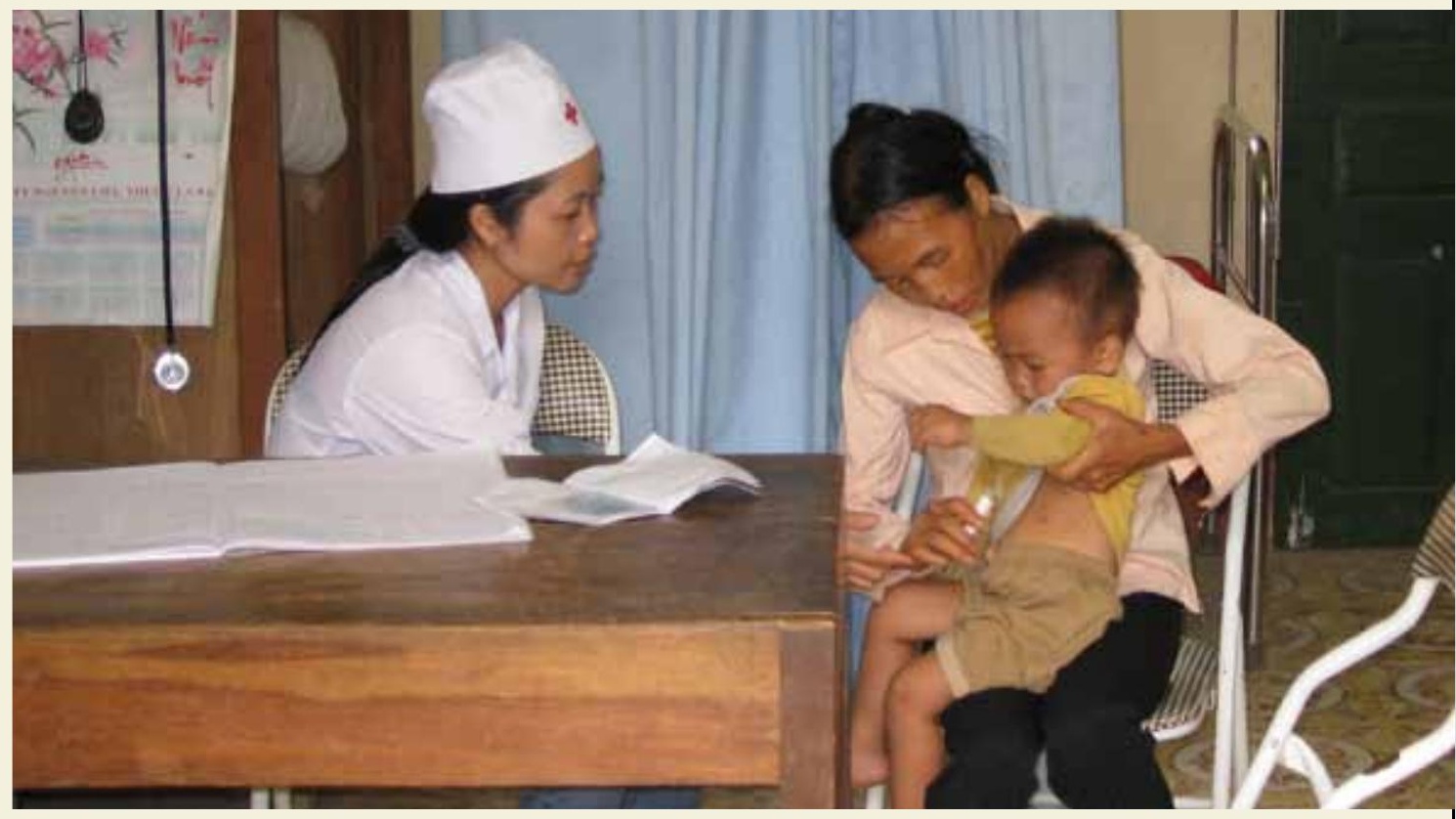




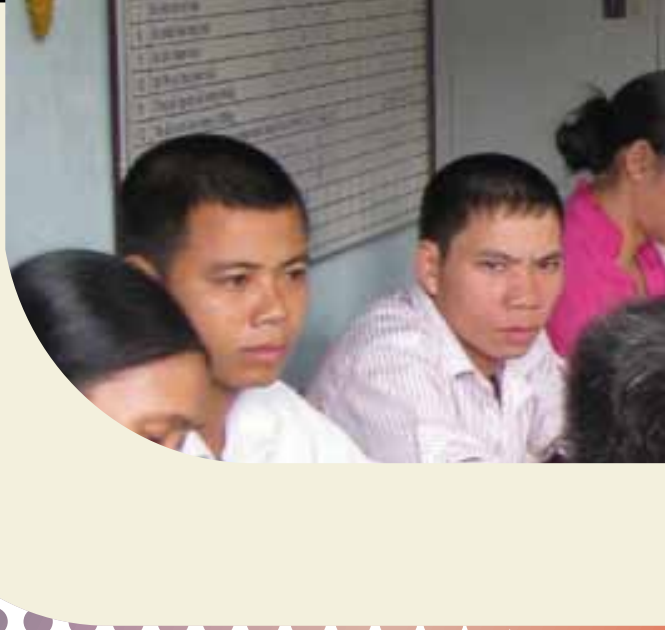

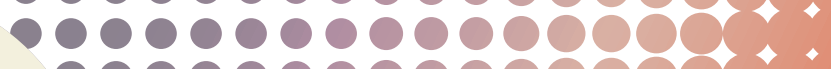

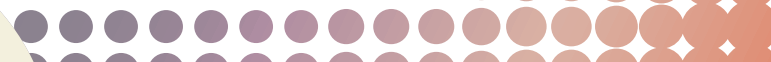

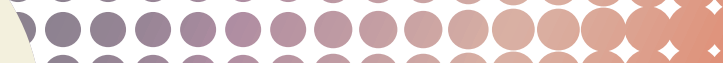

000000000

00000000

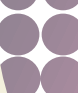

\section{USING EVIDENCE}

\section{FOR PROGRAM MANAGEMENT}

With an enriched and usable body of evidence in hand, attention must turn to the ability of TNHD to use such evidence to improve program operations. For the foreseeable future, it is not possible to place highly trained research staff at provincial levels. Instead it is necessary to create a culture of evidence-based program management throughout the department.

For this, TNHD has created an Evidence Based Unit at provincial $H Q$, drawn from existing staff with appropriate potential. Thai Nguyen University of Medicine and Pharmacy has the potential to serve as a locally available source of expertise in obtaining, interpreting and using research information. And the availability of computers at all levels of the system will allow health staff to find and use the data they need to improve their work.

The partners, led by Ha Noi Medical University, are now in the process of determining how best to utilize these assets, through training, mentoring and practice. This long-term process will result in a model of great potential value to Viet Nam. 


\section{VƯONN TỚl NHŨ̃NG ĐỐl TƯƠNG ÍT ĐƯỢC PHỤC VỤ}

Bằng việc đạt được nhưng mục tiêu như đề ra ở trên, dự án này cố gắng đạt được một mục tiêu quan trong khác: sự công bằng trong y tế ở tỉnh Thái Nguyên. Nhóm dân số dễ b! tổn thương tại Việt Nam như nhóm ngươi nghèo, dân tộc thiểu số và nhứng cư dân sinh sống ở vùng xa xôi, hẻo lánh phải đối mặt với những bất lọi trong y tế. Mặc dù hầu hết các xã trong tỉnh Thái Nguyên với đa số dân là người Kinh, khoảng một phần tư dân số thuộc nhóm dân tộc thiểu số như Tày, Nùng và Dao. Dân tộc thiểu số tại tỉnh Thái Nguyên có xu hướng là nhưng người nghèo khó và sống ở những vùng xa xôi hẻo lánh và cuung cũng là nhóm người có tỷ lệ sử dụng TYT xã khá cao.

Do vậy, cải thiện hệ thống chăm sóc y tế tại tuyến xã thông qua việc phát triển phần mềm Quán Lý Thông Tin $Y$ Tế cúng giúp STYTN và các đối tác có thể phục vụ tốt hơn nhu cầu y tế của nhóm nguời dân dễ b! tổn thương. Ví dụ: có thể gọi ra các màn hinh máy tính cho phép cán bộ y tế tuyến xã xác định và phục vụ trẻ em b! suy dinh dương, nhưng trẻ em chưa được tiêm chủng đúng hạn, hoặc nhứng người cần được chăm sóc sức khỏe sinh sản. Hơn nữa, các nghiên cứu có phạm vi lớn hơn hiện nay đang được HĐDSVN thực hiện với các đối tác sẽ tộp trung đặc biệt vào các vấn đề liên quan dến cộng đồng dân số dễ b!̣ tổn thương nhằm tập trung hơn nữa các nỗ lực và nguồn lực vào các đối tuợng này. Thông qua việc cái thiện luồng thông tin, chênh lệch công bằng ở nhưng nơi như Thái Nguyên có thể sẽ giám dần.

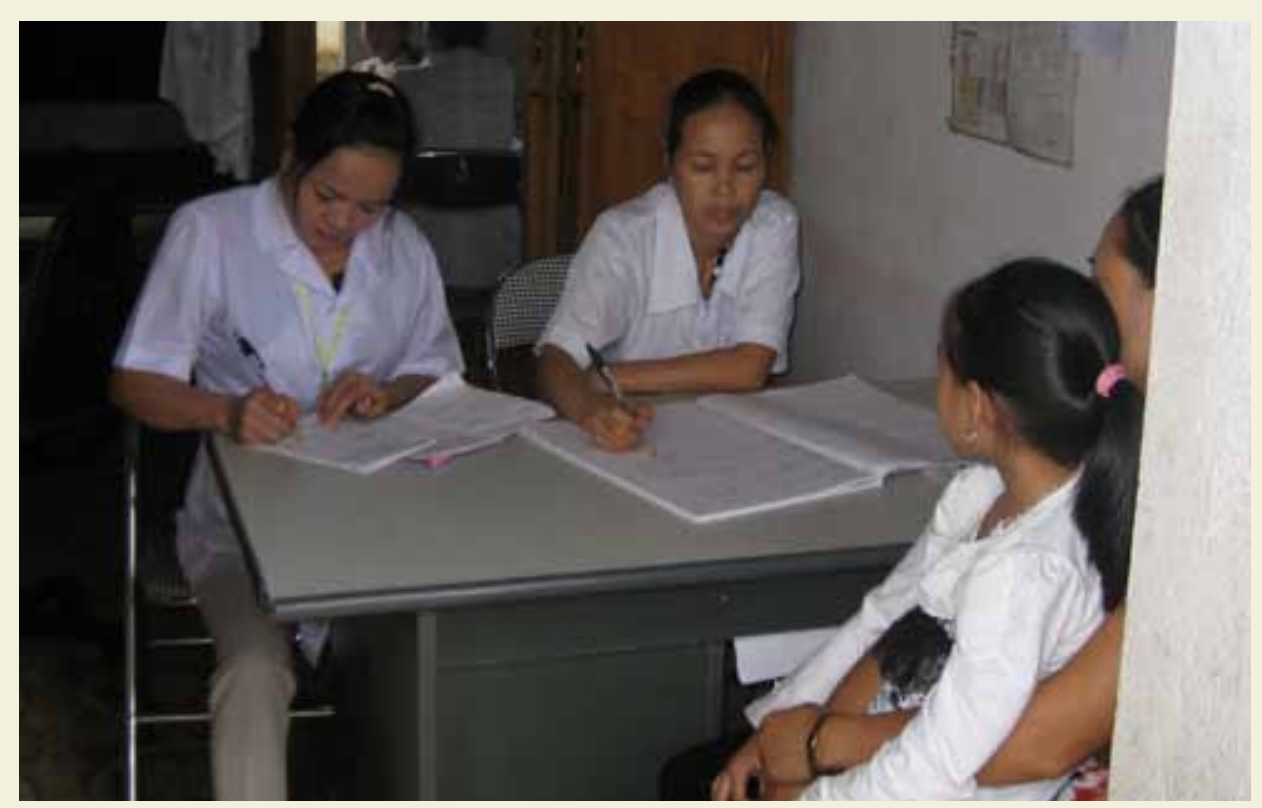



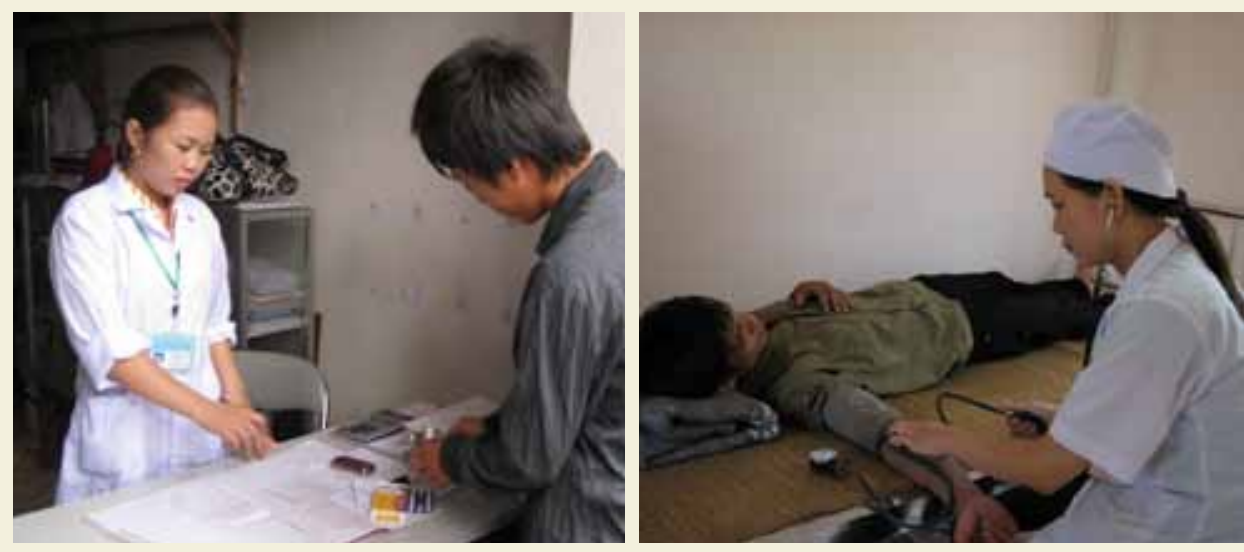

\section{REALIZING THE VISION: IMPLICATIONS FOR VIET NAM}

The vision embedded in this project is not only a functioning, computerized HMIS system, but a model for obtaining and using evidence for improving health that can be used throughout Viet Nam. We are designing the system to make it as usable as possible with minimal changes to the existing system or resources.

The computerization of commune-level HMIS data is only a part of the larger task of creating an IT-based Health Information System throughout Viet Nam, which is currently a high priority for the Ministry of Health. Our aim is to contribute to that component both by developing, testing and revising the required software, and learning how best to use it. The computerized HMIS should provide the system with better and more timely routine reports, and provide a platform for managers throughout the system to make incremental, short-term improvements in their operations.

At the same time, we are also aiming to provide a model for using a broader range of evidence, from service data and from various types of research studies, not only from within the province but throughout Viet Nam, to equip managers with as wide a range as possible of evidence to improve health. 


\section{HIỆN THỰC HÓA TẦM NHIIN: Ý NGHITA CHO VIẸT NAM}

Tầm nhìn trong dự án này không chỉ là một hệ thống Quản Lý Thông Tin Y Tế HMIS được tin học hóa và có thể hoạt dộng, mà còn là một mô hình nhằm đạt được và sử dụng bằng chứng trong việc cái thiện y tế có thể được sử dụng trên toàn Việt Nam. Chúng tôi đang thiết kế một hệ thống có thể sử dụng được, hạn chế tối đa việc thay đổi hệ thống hoặc nguồn lực hiện tại.

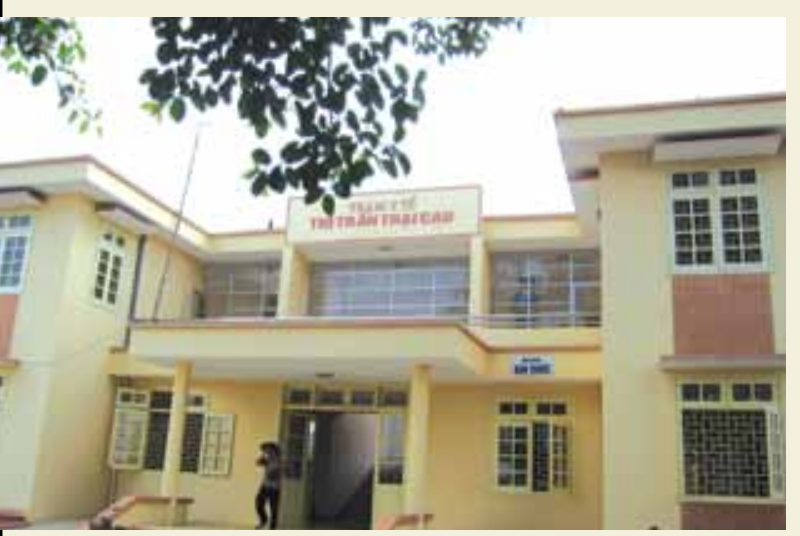

Việc tin học hóa các dữ liệu có trong phần mềm Quán Lý Thông Tin Y Tế xã, phường, th! trấn HMIS chỉ là một phần trong một nhiệm vụ lớn hơn là xây dựng một hệ thống thông tin y tế dựa trên công nghệ thông tin cho toàn Việt Nam, nhiệm vụ này hiện đang là ư tiên hàng đầu của Bộ $Y$ Tế Việt Nam. Mục tiêu của chúng tôi là góp phần vào nhiệm vụ đó, không chỉ bằng cách phát triển, thử nghiệm và sứa đổi phần mềm mà còn học cách sử dụng nó một cách tốt nhất. Phần mềm Hệ Thống Quản Lý Thông Tin $Y$ Tế, sẽ cung cấp cho hệ thống y tế các báo cáo thường quy đúng thời hạn với chất lượng tốt hơn và nền tảng cho các cán bộ quản lý thông qua hệ thống phần mềm có thể sớm cái thiện các hoạt động của mình.

Cùng lúc đó, chúng tôi cũng đề ra mục tiêu cung cấp một mô hình sử dụng một loạt các bằng chứng đầy đủ hơn không chỉ từ dữ liệu dịch vụ mà còn từ một loạt các nghiên cứv; không chỉ được thực hiện trong tỉnh Thái Nguyên mà trên khắp Việt Nam, để cung cấp cho các cán bộ cấp quản lý càng nhiều bằng chứng càng tốt nhằm cải thiện hệ thống $\mathrm{y}$ tế. 


\section{THE PARTNERS}

\section{Thai Nguyen Health Department (TNHD)}

TNHD manages all health-related activities, including technical, financial planning and administrative affairs in Thai Nguyen and is primarily responsible for the development of the provincial primary health care system. Through an existing grant from the Atlantic Philanthropies and additional funds from the Thai Nguyen People's Committee, TNHD is constructing/upgrading all CHCs within the province and providing them with new clinical equipment and computers. TNHD is committed to being in the forefront of efforts to computerize health information systems in Viet Nam.

\section{Thai Nguyen University of Medicine and Pharmacy (TNUMP)}

TNUMP is the only tertiary educational institution in Vietnam's northern mountainous region, and trains doctors, nurses and pharmacists to serve more than 10 million residents in 25 provinces of the region. It has substantial capacity building experience, and has carried out valuable research in reproductive health and related issues in support of this project. TNUMP is expected to be a sustained source of support to TNHD for the implementation of the EBPM model in Thai Nguyen.

\section{Institute of Population, Health and Development (PHAD)}

The Institute of Population, Health and Development is a leading social science and health research institute based in $\mathrm{Ha}$ Noi. It strives to investigate and address the full range of factors that influence health and wellbeing of populations. With PCVN, PHAD is evaluating the effect of the HMIS upgrade on CHC performance, and is conducting studies on key health issues in Thai Nguyen province including reproductive health and abortion, quality of care and health seeking behavior, and non-communicable diseases such as hypertension.

\section{Hitechnology Services Providing and Solutions Company (HSP)}

HSP is a software company specializing in programming hospital management software. Under the direction of PCVN, HSP has developed a unique communebased HMIS software for TNHD, meeting both international interoperability standards and Viet Nam MOH's reporting standards and requirements. HSP is also responsible for training and software maintenance in support of the system.

\section{Hanoi Medical University (HMU)}

Founded in 1902, Ha Noi Medical University is the oldest modern university in Viet $\mathrm{Nam}$, and is considered one of the leading medical schools in the country; it is also the newest partner in the project. Its primary role is to strengthen the capacity of TNHD in utilizing evidence, working with TNUMP to design and implement shortterm courses and the placement of consultants and interns. 


\section{ĐỐl TÁC}

\section{Sở Y Tế Thái Nguyên}

SYTTN quán lý toàn bộ các hoạt động liên quan đến y tế bao gồm công tác lập kế hoạch tài chính, chuyên môn và công tác hành chính tại tỉnh Thái Nguyên và chịu trách nhiệm chủ yếu trong việc phát triển hệ thống chăm sóc súc khỏe ban dầu của toàn tỉnh. Thông qua dự án do tổ chức Atlantic Philanthropies tài trợ và kinh phí từ Úy Ban Nhân Dân Tỉnh Thái Nguyên, SYTTN hiện nay đang thực hiện xây dưng/nâng cấp toàn bộ các TYT xã trong toàn tính và trang b! các thiết b! y tế và máy tính mới cho các TYT xã. SYTTN cam kết là đơn v! đi tiên phong trong nố lực tin học hóa Hệ Thống Quản Lý Thông Tin Y Tế tại Việt Nam.

\section{Đại Học Y Dược Thái Nguyên (ĐHYDTN)}

ĐHYDTN là cơ quan giáo dục đại học duy nhất trong khu vực miền núi phía bắc Việt Nam, đào tạo bác sĩ, diều dưỡng và dược sĩ để phục vụ cho trên 10 triệu dân trong 25 tính thành trong khu vực này. ĐHYDTN có kinh nghiệm xây dựg năng lực đáng kể và cuñng đẫ thực hiện nhiều nghiên cứu về Sức Khỏe Sinh Sán và các vấn dề liên quan rất có giá trị trong khuôn khổ dự án này. ĐHYDTN được mong đợi trở thành nguồn lực bền vững để giúp SYTTN trong việc thực hiện mô hình Quán Lý Dựa Trên Bằng Chứng tại tỉnh Thái Nguyên.

\section{Viện Dân Số, Súc Khỏe và Phát Triển}

Viện Dân Số, Sức Khỏe và Phát Triển là một cơ quan nghiên cứu y tế và khoa học xã hội hàng dầu có trụ sở tại Hà Nội. Viện phấn dấu diều tra và giái quyết đầy dú các nhân tố có ảnh hưởng đến y tế và sức khỏe cưa ngườ dân. Cùng với HĐDSVN, Viện hiện đang đánh giá å̉nh hưởng của phần mềm Quán Lý Thông Tin $Y$ Tế xã , phường, th! trấn HMIS trong việc cái thiện công việc của các TYT xã và dang thực hiện một loạt các nghiên cứ về các vấn đề y tế chủ yếu tại tính Thái Nguyên bao gồm các vấn đề về sức khỏe sinh sản và nạo phá thai; chất lượng chăm sóc và các hành vi tim kiếm dịch vụ y tế và các bệnh không truyền nhiễm nhu cao huyết áp.

\section{Công ty CP Cung Cấp Giải Pháp và Dịch Vụ Công Nghệ Cao HSP}

HSP là một công ty phát triển phần mềm chuyên về quán lý bệnh viện. Duới sự chí đạo của HĐDSVN, công ty CP HSP dã phát triển một phần mềm Quản Lý Thông Tin Y Tế xã, phường, th! trấn HMIS dồng nhất cho SYTTN đạt cả các tiêu chuẩn vận hành quốc tế và cá theo mẫu báo cáo và yêu cẩu của Bộ $Y$ Tế Việt Nam. Công ty CP HSP cũng chịu trách nhiệm đào tạo và duy trì báo duỡng phần mềm.

\section{Đại Học Y Hà Nội (ĐHYHN)}

Được thành lập từ năm 1902, ĐHYHN là trường đại học hiện đại lâu đời nhát Việt Nam và được coi là một trong nhứng trường đào tạo bác sĩ hàng đầu của Việt Nam, $Đ H Y Y N N$ cũng là dối tác mới nhất của HĐDSVN trong dự án này. Vai trò chính của ĐHYHN là nâng cao năng lực cho SYTTN trong việc sử dụng bằng chúng, phối họp với ĐHYDTN thiết kế và thực hiện các khóa đào tạo ngắn hạn và cung cấp cán bộ tư vấn và thực tộp. 


\section{ABOUT THE POPULATION COUNCIL}

The Population Council confronts critical health and development issues - from stopping the spread of HIV to improving reproductive health and ensuring that young people lead full and productive lives. Through biomedical, social science, and public health research in 50 countries, we work with our partners to deliver solutions that lead to more effective policies, programs, and technologies that improve lives around the world. Established in 1952 and headquartered in New York, the Council is a nongovernmental, nonprofit organization governed by an international board of trustees.

\section{GIỚl THIỆU SƠ LƯỢC VỀ Hộl ĐỒNG DÂN SỐ (HĐDS)}

Hội Đồng Dân Số đương đầu với các vấn đề về phát triển và sức khỏe then chốt - từ ngăn chặn sự lây truyền HIV đến cải thiện sức khỏe sinh sản và đảm bảo nhóm người trẻ tuổi có được cuộc sống hữu ích và đầy đủ. Qua các nghiên cứu về y sinh, khoa học xã hội và y tế công cộng ở 50 quốc gia, chúng tôi làm việc với các đối tác của mình để mang lại các giái pháp tạo ra các chính sách, chương trình và công nghệ có hiệu quả hơn nhằm cái thiện cuộc sống trên toàn thế giới. Được thành lập từ năm 1952 với trụ sở chính đặt tại New York, Hội Đồng Dân Số là một tổ chức phi chính phủ, phi lợi nhuận, được một ban quản tr! quốc tế quản lý.

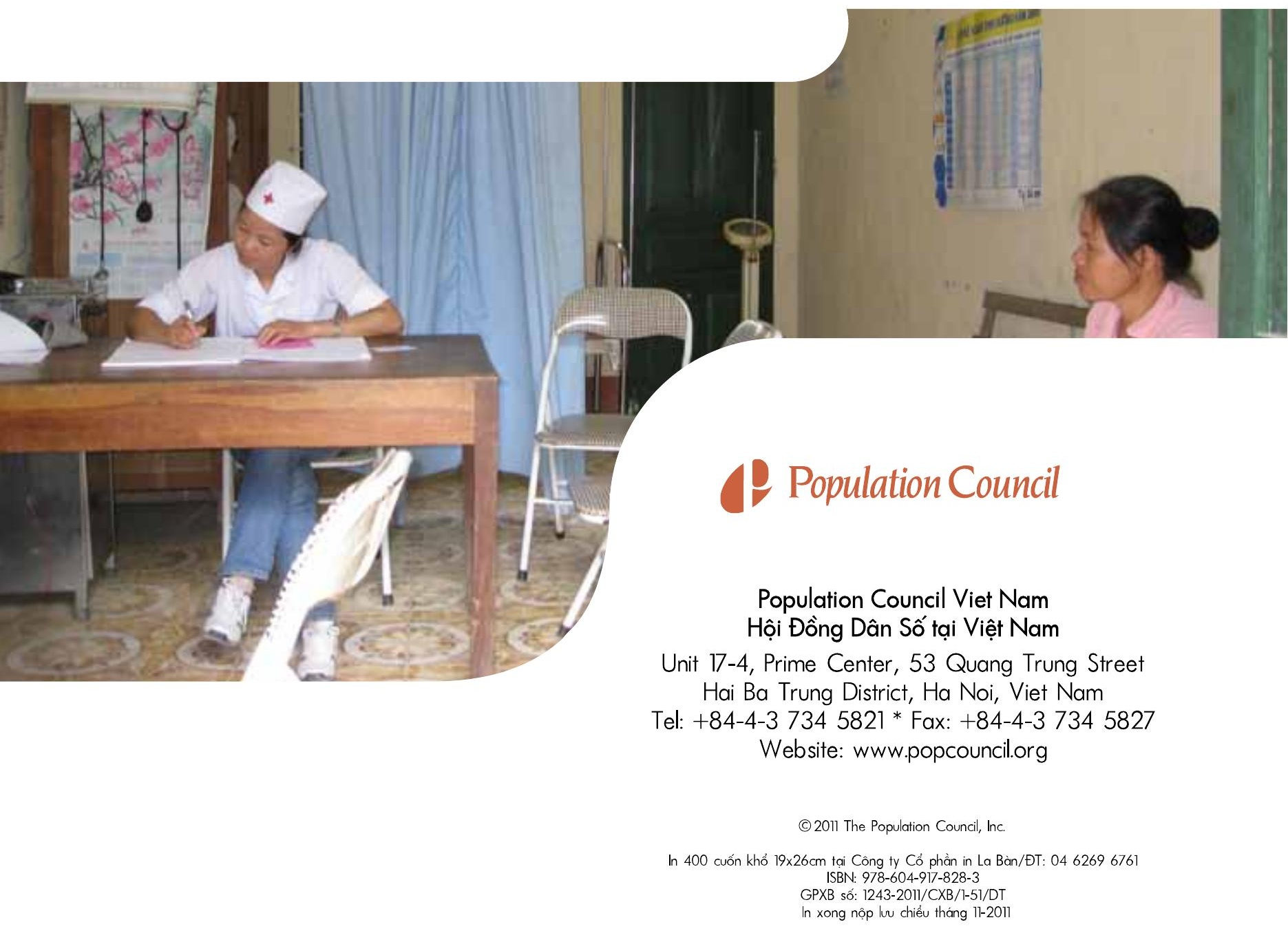

